Zeszyty Naukowe Szkoły Głównej Gospodarstwa Wiejskiego w Warszawie Problemy Rolnictwa Światowego tom 17 (XXXII), zeszyt 1, 2017: 216-225

DOI: 10.22630/PRS.2017.17.1.20

Danuta Zawadzka ${ }^{1}$

Instytut Ekonomiki Rolnictwa i Gospodarki Żywnościowej - Państwowy

Instytut Badawczy w Warszawie

\title{
Zmiany strukturalne na rynku trzody w Stanach Zjednoczonych i ich wpływ na cykl świński
}

\section{Structural Changes on the Hog Market in the USA and Their Impact on the Hog Cycle}

\begin{abstract}
Synopsis. W ostatnich dwudziestu latach rynek wieprzowiny w Stanach Zjednoczonych został poddany głębokim przemianom polegających na koncentracji podmiotów na wszystkich poziomach produkcji trzody i wieprzowiny oraz na postępie w koordynacji pionowej. Duża skala produkcji zaangażowanie dużego kapitału nie pozwalają producentom na ograniczanie produkcji w okresie spadku cen trzody. W rezultacie wahania podaży, a więc najistotniejszy element w mechanizmie „cyklu świńskiego" charakteryzuje się malejącą amplitudą wahań. Oznacza to zmianę modelu pajęczyny z periodycznego na model wahań zbieżnych. Pomimo relatywnie małych wahań produkcji, ceny trzody cechuje tak samo duża amplituda wahań i częstość ich występowania jak w poprzednich dziesięcioleciach. Dzieje się tak, $\mathrm{z}$ dwu powodów. $\mathrm{Z}$ jednej strony zgodnie $\mathrm{z}$ teorią ekonomii usztywnionemu popytowi towarzyszy giętkość cen. $Z$ drugiej strony na ceny trzody wpływ mają także kursy dolara do walut krajów, z którymi Stany Zjednoczone prowadzą handel zagraniczny.
\end{abstract}

Słowa kluczowe: cykl świński, koncentracja, koordynacja pionowa

\begin{abstract}
In the last twenty years, the pork meat market in the United States was modified in many aspects including changes in concentration of the pig and pork production as well as on progress in the vertical coordination. The large production and the involvement of large capital does not allow producers to restrict production in a period of falling prices of pigs. As a result, fluctuations in supply, being the most important element of "hog cycle" is characterized by decreasing their amplitude. It is accompanied by changing of the cobwebs model from periodic to convergent fluctuations. However, regardless of small variations in production, pig prices are characterized by the same large amplitude fluctuations and their frequency as in previous decades. This happens due to two reasons. On the one hand, according to economic theory inelastic demand is accompanied by flexibility of prices. On the other hand, the pig prices are influenced by exchange rates of currencies with respect to dollar of the countries trading with the United States. Celem badań jest przedstawienie tych zależności.
\end{abstract}

Key words: hog cycle, concentration, vertical coordination

\section{Wprowadzenie}

Pod pojęciem „cyklu świńskiego” rozumie się rodzaj wahań wielkości pogłowia i produkcji trzody chlewnej zaliczanych do tzw. cyklów specjalnych, czyli mających swój własny mechanizm" (Małkowski, 1998). Do literatury przedmiotu pojęcie to zostało wprowadzone w 1876 r. w Stanach Zjednoczonych przez S. Bennera ${ }^{2}$, a za teoretyczne

\footnotetext{
${ }^{1}$ dr, Zakład Badań Rynkowych IERiGŻ-PIB, ul. Świętokrzyska 20, 00-002 Warszawa,

e-mail: Danuta.Zawadzka@ierigz.waw.pl

${ }^{2}$ Fakt ten wspominają m.in. St. Schmidt i St. Mandecki 1933.
} 
wyjaśnienie zjawiska uważa się tzw. „teoremat pajęczyny” sformułowany przez M. Ezekiela ${ }^{3}$. W Europie badania cyklu świńskiego, jako pierwszy zapoczątkował A. Hanau (1927), a w Polsce dwu przedwojennych badaczy, a mianowicie St. Schmidt i St. Mandecki (1933). Ten ostatni kontynuował badania także po wojnie wraz z J. Steczkowskim (Schmidt, Steczkowski, 1960; Schmidt, Steczkowski, 1975). Kontynuatorami badań mechanizmu cyklu świńskiego byli też w kolejności Z. Kozłowski, H. Chojnacka oraz J. Małkowski (Zawadzka, 2006A, Zawadzka, 2014).

Pomimo, że pojęcie „,cykl świński” funkcjonuje w nauce światowej od ponad stu lat i przez ten okres doczekało się bardzo bogatej literatury, tak polskiej jak i światowej, to sam problem cyklicznych wahań produkcji i cen trzody jest stale aktualny i wymaga ciagłłej uwagi, gdyż w zmieniających się gospodarkach zmienia się także mechanizm cyklu świńskiego. $Z$ naszych obserwacji wynika, że zmiany takie nastapiły $w$ ciagu ostatnich około dwudziestu lat w Stanach Zjednoczonych. Przyczyn obserwowanego zjawiska upatrywać można w transformacji rynku wieprzowiny, która miała miejsce w tym okresie.

Stany Zjednoczone były do niedawna najlepszym przykładem kraju, w którym „,cykl świński” przebiegał wręcz modelowo, tzn. z zachowaniem właściwych mu cech, takich jak regularność i rytmiczność [Małkowski J. 1986, Małkowski J. 1998]. Wahania ubojów i cen trzody miały charakter periodyczny. Działo się tak, dlatego że przebieg wahań cyklicznych nie był zakłócany ani poprzez stosowanie interwencji, ani też innych instrumentów polityki rolnej oddziałujących na ten rynek. Krzywa podaży (ubojów trzody) wykazywała więc wyraźne minima i maksima, powtarzające się, co 3-4 lata. Każdemu wzrostowi ubojów towarzyszył spadek cen trzody, a każdemu spadkowi ubojów odpowiadał wzrost cen. Inaczej mówiąc maksymalnej podaży trzody towarzyszyły minimalne jej ceny, a minimalnej podaży maksymalne ceny.

Celem badań jest wskazanie zmian, jakie nastąpiły w wybranych elementach mechanizmu cyklu świńskiego w Stanach Zjednoczonych, w ostatnich około dwudziestu latach oraz próba określenia przyczyn tych zmian. Obserwuje się, że przebieg wahań ubojów trzody jest odmienny od ich przebiegu we wcześniejszych latach, a co najważniejsze nieadekwatny do wahań cen trzody. Sądzić można, że jest to wpływ zmian strukturalnych, jakie dokonały się na tym rynku. Około połowy lat dziewięćdziesiątych przybrał bowiem na sile proces koncentracji podmiotów we wszystkich ogniwach łańcucha marketingowego, a przede wszystkim dokonał się postęp w zakresie koordynacji pionowej, skutkujący diametralną zmianą kanałów rynku i metod wyceny tuczników.

\section{Dane i metody}

Badania obejmują lata 1970-2015. Tylko tak długi okres pozwala bowiem na przedstawienie analizowanego problemu. Chodzi o to by móc dokonać porównania amplitudy wahań w różnych okresach. Do badań użyto danych miesięcznych dotyczących ubojów i cen trzody w Stanach Zjednoczonych. Jedynie taki rodzaj danych może być podstawą badań cyklu świńskiego. Podstawowym źródłem danych statystycznych były publikacje NASS/USDA. Celem wyeliminowania wahań sezonowych i przypadkowych obliczono średnie ruchome scentrowane dwunastomiesięczne dla poszczególnych szeregów czasowych, które stały się podstawą wyznaczenia linii trendu oraz obliczenia odchyleń od

\footnotetext{
${ }^{3}$ op.cit.
} 
trendu. Siłę współzależności między cenami trzody a kursami walut obliczono przy pomocy współczynników korelacji liniowej Pearsona.

\section{Charakterystyka zmian strukturalnych na rynku trzody w Stanach Zjednoczonych}

Najbardziej ewidentnym dowodem przemian strukturalnych $\mathrm{w}$ produkcji trzody, w Stanach Zjednoczonych jest drastyczny spadek liczby gospodarstw. Proces ten trwa od wielu lat, ale wciąż jest intensywny. Tylko w latach 2000-2010 liczba gospodarstw zajmujących się chowem trzody zmniejszyła się o $20 \%$, a pogłowie przypadające na 1 gospodarstwo wzrosło z 675 sztuk do 936 (Zawadzka D. 2014). W 2012 r. liczba gospodarstw wynosząca 66 tys. była mniejsza o następne $5 \%$, a pogłowie przypadające na 1 gospodarstwo wzrosło do 1045 sztuk, a więc o 12\%. Cechą charakterystyczną koncentracji produkcji trzody w Stanach Zjednoczonych jest stały wzrost liczby gospodarstw największych, a więc o średniej skali produkcji wynoszącej 5000 i więcej sztuk trzody. W latach 2000-2012 liczba takich gospodarstw zwiększyła się ponad trzykrotnie. Pomimo to jest ona relatywnie mała, w odniesieniu do liczby gospodarstw najmniejszych, a więc utrzymujących stada mniejsze niż 100 sztuk. Tym niemniej ta stosunkowo nieliczna grupa producentów trzody, charakteryzuje się dużą i stale rosnąca skalą produkcji, co decyduje o wysokiej średniej wielkości pogłowia przypadającej na 1 gospodarstwo. W 2012 roku, 84\% gospodarstw spośród gospodarstw posiadających trzodę prowadziło chów o skali mniejszej niż 1000 sztuk, a 88\% gospodarstw o skali mniejszej niż 2000 sztuk. Udział tych gospodarstw w ogólnym pogłowiu wynosił jednak odpowiednio 4\% i 9\%. Tymczasem tylko $12 \%$ gospodarstw posiadało trzodę w stadach powyżej 2000 sztuk, w tym $5 \% \mathrm{w}$ stadach powyżej 5000 sztuk, ale ich udział w ogólnym pogłowiu wynosił odpowiednio $91 \%$ i $68 \%$ (tabela 1 ).

Tabela 1. Struktura gospodarstw posiadających trzodę oraz pogłowia trzody wg skali chowu w USA

Table 1. Structure of farms with hog and pig inventory according to the scale of farming in USA

\begin{tabular}{l|cccc}
\hline $\begin{array}{c}\text { Gospodarstwa wg skali } \\
\text { produkcji trzody }\end{array}$ & $\begin{array}{c}\text { Liczba } \\
\text { gospodarstw }\end{array}$ & Pogłowie trzody & $\begin{array}{c}\text { Liczba } \\
\text { gospodarstw }\end{array}$ & Pogłowie trzody \\
\hline Ogółem: & 100 & 100 & 100 & 100 \\
$1-99$ szt. & 58 & 3 & 75 & 1 \\
$100-499$ & 26 & 18 & 6 & 1 \\
$500-999$ & 9 & 17 & 3 & 2 \\
$1000-1999$ & 4 & 17 & 4 & 5 \\
$2000-4999$ & 2 & 17 & 7 & 23 \\
5000 i więcej & 1 & 28 & 5 & 68 \\
\hline
\end{tabular}

Źródło: obliczenia własne na podstawie danych NASS/USDA.

Bezpośrednim następstwem wysokiej koncentracji chowu trzody jest wysoka koncentracja podaży trzody. Podobnie jak w przypadku pogłowia, także w tym ogniwie, postęp w zakresie koncentracji dokonał się w wyniku szybkiego wypieraniu z rynku 
najmniejszych dostawców. W ciagu ostatnich około dwudziestu lat, w Stanach Zjednoczonych drastycznie zmniejszył się udział podaży pochodzącej od producentów o najmniejszej skali podaży.

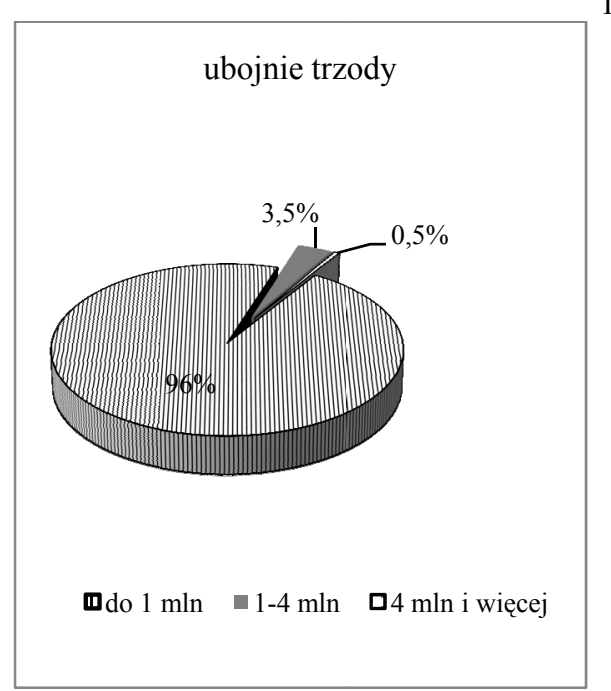

1995

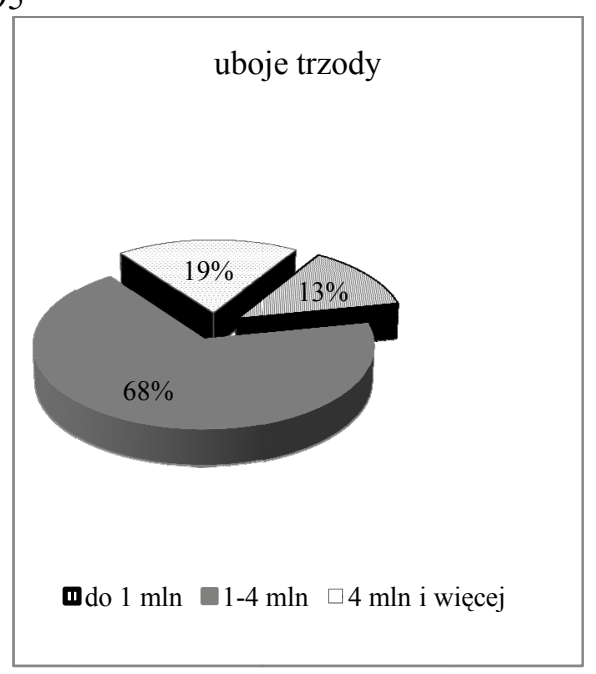

2014
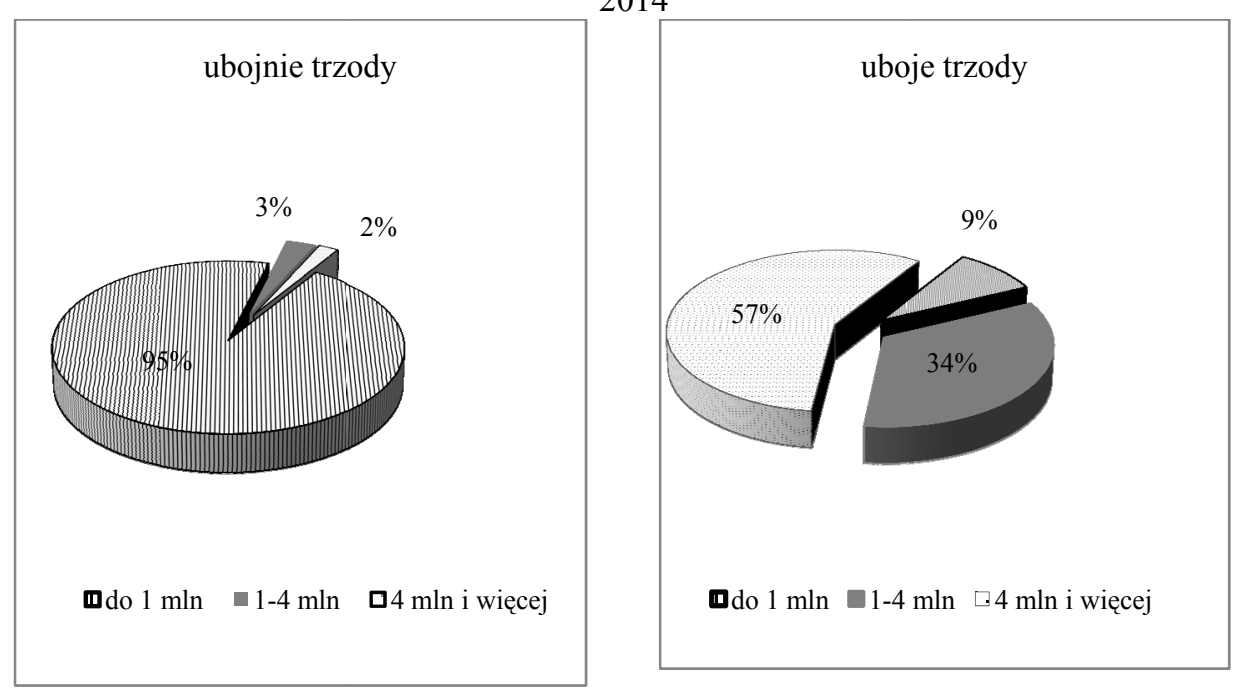

Rys. 1.Struktura ubojni i ubojów trzody wg wielkości ubojów w Stanach Zjednoczonych w 1995 r. i 2014 r.

Fig. 1.The structure of slaughter plants and hog slaughtered by hog slaughter size group, USA, 1995 and 2014 Źródło: opracowanie własne na podstawie danych NASS-USDA

W 2012 roku, podaż pochodząca od producentów dostarczających rocznie do uboju mniej niż 1 tys. tuczników stanowiła niecały $1 \%$, podczas gdy jeszcze w połowie lat dziewięćdziesiątych udział tych producentów kształtował się na poziomie około $20 \%$. W okresie tym w największym stopniu wzmocniła się siła ekonomiczna największych 
producentów, czyli dostarczających rocznie na rynek więcej niż 5000 tuczników. Ich udział w rynku powiększył się z 17\% w 1995 do 51\% w 2000 r. i 91\% w 2012 r.

W Stanach Zjednoczonych, w 2014 roku funkcjonowało 620 ubojni trzody pod nadzorem federalnym ${ }^{4}$. Wśród nich dominowały ubojnie małe, czyli o rocznych ubojach mniejszych niż 10 tys. sztuk (388 ubojni). Stanowiły one 63\% ogólnej liczby ubojni pod nadzorem federalnym. Uboje $w$ nich dokonywane stanowily jednak zaledwie $0,1 \%$ ogólnych ubojów trzody. Tymczasem udział ubojni o rocznych ubojach większych niż 1 mln tuczników wynosił niecałe $5 \%$ ogólnej liczby ubojni, ale ich udział w ubojach kształtował się na poziomie 91\%. Oznacza to, że dzienny ubój w tych zakładach kształtował się na przeciętnym poziomie ponad 13 tys. tuczników. Jednocześnie z danych NASS/USDA wynika, że w 2014 roku około 60 mln tuczników, czyli ponad połowę krajowych ubojów, dokonano jedynie w 12 ubojniach o rocznej skali ubojów większej niż 4 mln sztuk. Dzienny ubój w tych zakładach wynosił około 20 tys. tuczników. Tak wysoka skala ubojów wynika z ciaggego dążenia do zmniejszania kosztów ubojów. Jak podają Barkema, Drabenstott, Novack (2001) koszty uboju w zakładach o rocznej skali ubojów większej niż $4 \mathrm{mln}$ sztuk są o około $25 \%$ niższe aniżeli w zakładach ubijających rocznie od 1 do 4 mln sztuk trzody (rys. 1).

W ostatnich kilkunastu latach w Stanach Zjednoczonych dokonał się także duży postęp w zakresie koordynacji pionowej ${ }^{5}$, która może być realizowana w oparciu o trzy podstawowe formy więzi ekonomicznej, a więc o wolny rynek, zawarcie kontraktu oraz nabycie tytułu własności lub stworzenie związku strategicznego. Pierwsza z wymienionych form jest formą tradycyjną i jednocześnie najprostszą. Ostatnia zaś traktowana jest, jako najbardziej zaawansowana postać koordynacji pionowej. Określa się ją mianem integracji pionowej. Postęp w zakresie koordynacji pionowej w Stanach Zjednoczonych miał na celu obniżenie kosztów, w tym głownie kosztów transakcyjnych. Efektem jego stała się diametralna zmiana kanałów zbytu tuczników i sposobu ich wyceny (Zawadzka, 2006A; Zawadzka, 2006B).

Jak podają, J. D. Lawrence, M. Hayenga (2002) jeszcze w 1993 roku głównym kanałem skupu był wolny rynek. Wówczas, ubojnie i zakłady przetwórcze kupiły na wolnym rynku około $87 \%$ trzody, w tym $68 \%$ poprzez własne stacje skupu, $17 \%$ poprzez dilerów i $2 \%$ na aukcjach terminowych. Pozostałe $13 \%$ trzody nabyto w drodze transakcji opartych o dhugoterminowe kontrakty handlowe (około $11 \%$ ) lub na podstawie kontraktów produkcyjnych (1\%). Własność ubojni czy zakładów przetwórczych stanowił $1 \%$ tuczników. Większość tuczników wyceniana była w oparciu o wagę żywą.

W 2015 r. na wolnym rynku skupiono jedynie 3,1\% tuczników, w tym $2,5 \%$ w oparciu o wage poubojową, a $0,6 \% \mathrm{w}$ oparciu o wagę żywą. Następne $65,8 \%$ tuczników skupionych było w oparciu o różnego rodzaju umowy kontraktacyjne zawierane między producentem, a ubojnią czy zakładem przetwórczym. Pozostałe 27,5\% tuczników stanowiło własność ubojni lub zakładu przetwórczego. tuczniki te wyceniane były w oparciu o wagę

\footnotetext{
${ }^{4}$ Ubojnie pod nadzorem federalnych są zakładami prowadzącymi działalność w obrębie co najmniej dwu Stanów. Zgodnie z przepisami, przy transporcie międzystanowym mięsa musi być zatrudniony inspektor federalny. W ubojniach tych dokonuje się 96-99\% całkowitych ubojów trzody na cele handlowe. Pozostałe 1- 4\% trzody jest ubijane w ubojniach lokalnych, czyli takich, które sprzedają i transportują mięso tylko w ramach jednego Stanu. Ubój w takich ubojniach nadzoruje inspektor stanowy.

${ }^{5} \mathrm{~W}$ literaturze przedmiotu pojęcie koordynacji pionowej definiowane jest, jako sukcesywny transfer produktu od producenta do konsumenta, lub synchronizacja kolejnych etapów produkcji, z uwzględnieniem ilości, jakości i czasu przepływu produktu (Martinez, 2002A; Martinez, 2002B).
} 
poubojową (Plain, 2016). W rezultacie tuczniki wyceniane w oparciu o wagę poubojową stanowiły łącznie 95,7\% wszystkich ubijanych tuczników. Najważniejszą sprawą jest jednak to, że na podstawie wyceny około $7 \%$ tuczników, wycenia się pozostałe $93 \%$, podlegające różnego rodzaju kontraktom.

\section{Zmiany cyklu świńskiego}

Przy pomocy średniej ruchomej scentrowanej dwunastomiesięcznej eliminującej sezonowość, przedstawiono ceny i uboje trzody w Stanach Zjednoczonych (rys. 2.). Obie krzywe charakteryzują się wyraźnie powtarzającymi się, co pewien czas, minimalnymi i maksymalnymi poziomami. Maksymalnym ubojom odpowiadają zawsze minimalne ceny trzody. Z kolei minimalnym ubojom towarzyszą maksymalne ceny. Porównując jednak prawą stronę wykresu, przedstawiającą rozwój cen i ubojów w ostatnich około dwudziestu latach, tj. 1995-2015 z jego lewą stroną, zauważamy, że wahania cen trzody były w ostatnich latach tak samo silne jak w latach siedemdziesiątych, ale wahania ubojów znacznie słabsze.

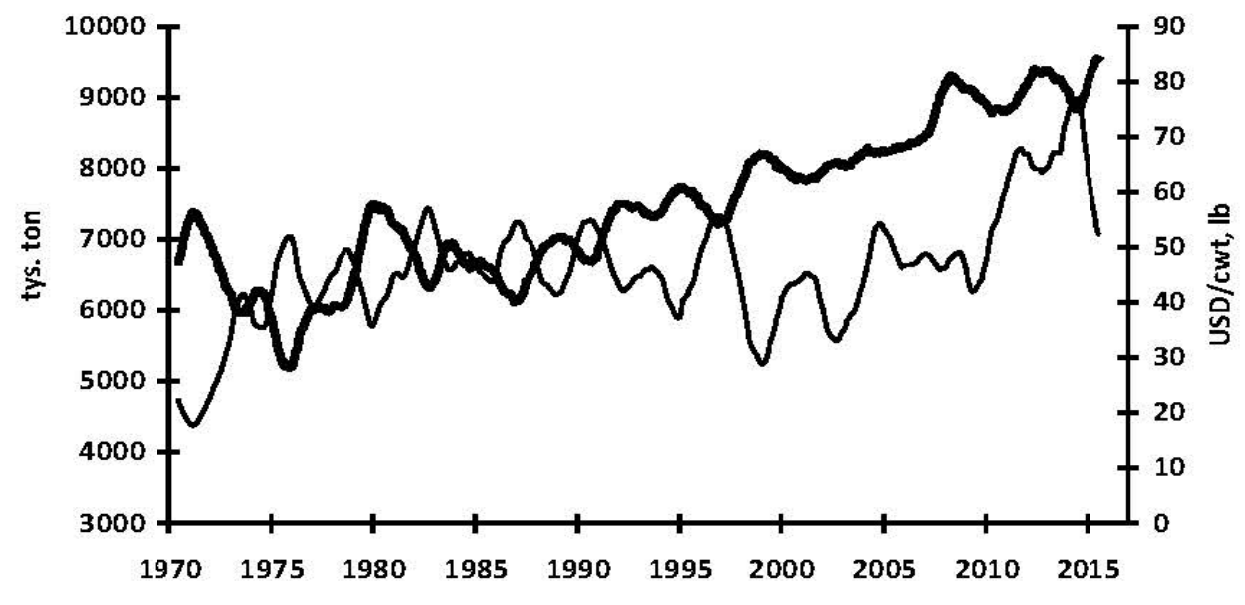

lata, miesiace

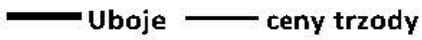

Rys. 2. Miesięczne uboje i ceny trzody w Stanach Zjednoczonych (po wyeliminowaniu sezonowości)

Fig. 2. Monhtly hogs slaughters and hog prices in United States (seasonally adjusted)

Źródło: opracowanie własne na podstawie danych NASS-USDA. 

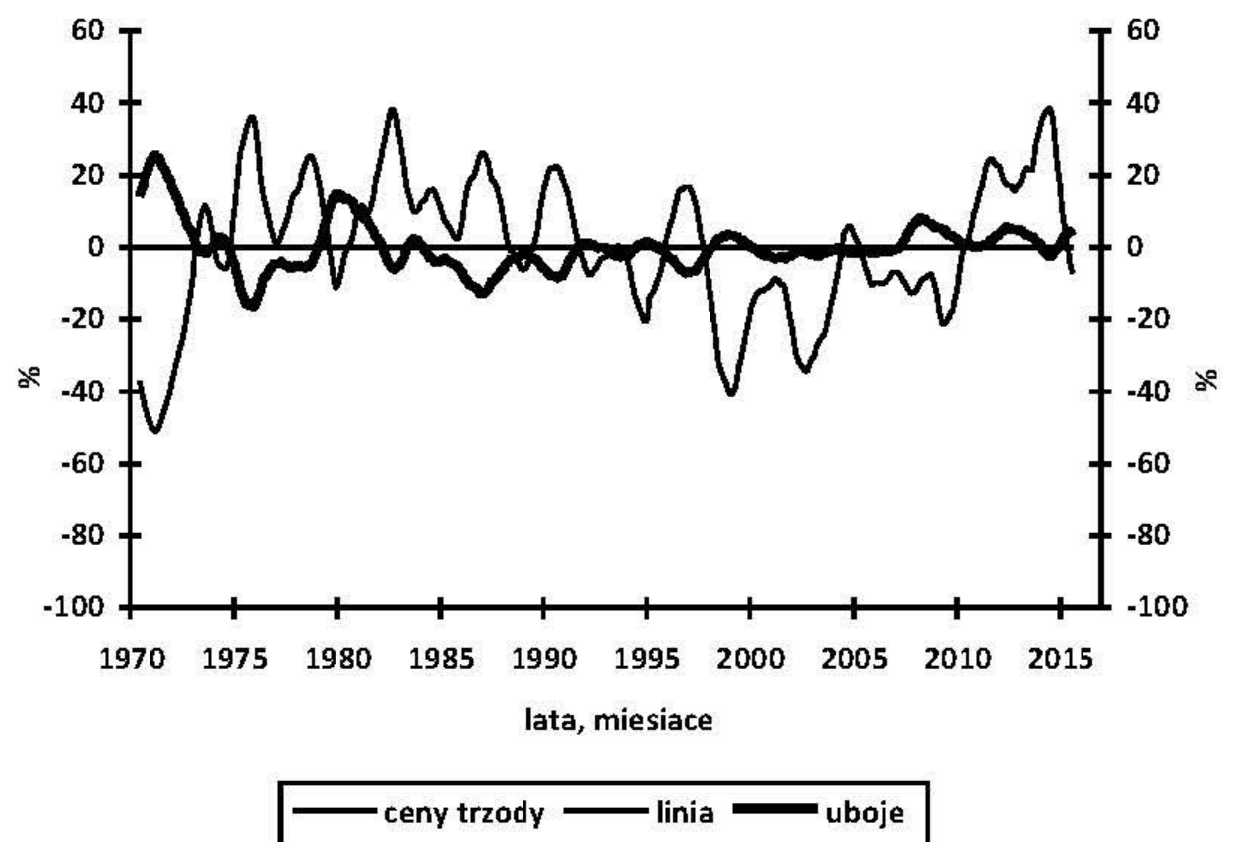

Rys. 3. Uboje i ceny trzody w Stanach Zjednoczonych, w \% odchyleń od trendu.

Fig. 3. Hog slaughters and prices in United State, in \% deviation from the trend line.

Źródło: opracowanie własne na podstawie danych NASS-USDA

Kwantyfikacją tego spostrzeżenia są odchylenia średniej ruchomej ubojów trzody od linii trendu (rys. 3). Z przeprowadzonych obliczeń wynika, że ekstremalne punkty odchyleń ubojów od linii trendu, zawierały się w latach 2010-2015, w granicach od minus 2,45 do plus $5,61 \%$, podczas gdy w latach siedemdziesiątych - od minus 16,57 do plus $25,76 \%$, w latach osiemdziesiątych od minus 13,01 do plus $14,95 \%$, w latach dziewięćdziesiątych od minus 8,63 do plus 3,66\%, a w latach $2000-2009$ od minus 3,33 do plus $8,15 \%$. Liczby te wskazują, że w przypadku ubojów mamy do czynienia z krzywą o wyraźnie malejącej amplitudzie wahań. Tymczasem ekstremalne punkty odchyleń średniej ruchomej cen trzody od linii trendu, w latach 2010-2015, zawierały się w granicach od minus 10,54\% do plus $38,42 \%$. Przedział ten był wprawdzie węższy niż w latach siedemdziesiątych czy dziewięćdziesiątych, kiedy ekstremalne punkty odchyleń zawierały się odpowiednio w granicach od minus 51,16 do plus $36,13 \%$ i minus 40,82 do plus $22,4 \%$, ale jednocześnie taki sam jak w latach osiemdziesiątych, kiedy zawierały się one w granicach od minus 11,23 do plus $38,19 \%$. W porównaniu z latami 2000-2009, amplituda wahań cen trzody była podobna, choć przedział odchyleń od linii trendu odmienny od minus 34,53 do plus $5,88 \%)$.

Malejąca amplituda wahań podaży świadczy, że mamy do czynienia z przypadkiem wahań zbieżnych, to jest takich, którym odpowiada mniejsza elastyczność podaży niż elastyczność popytu. Można zatem wnioskować, że na rynku trzody w Stanach Zjednoczonych pojawiły się czynniki usztywniające podaż względem cen. Czynnikiem 
takim jest z pewnością duża i w dodatku stale rosnąca skala produkcji trzody, która z jednej strony umożliwiła wprowadzenie nowych technologii i obniżenie kosztów produkcji, ale z drugiej strony spowodowała, że wzrósł udział kosztów stałych w ogólnych kosztach produkcji. Duże rozmiary skali produkcji i zaangażowanie dużego kapitału nie pozwalają producentom na ograniczanie produkcji $\mathrm{w}$ okresie spadku cen, a wręcz odwrotnie powoduja, że producenci chcąc utrzymać zysk na dotychczasowym poziomie produkują coraz więcej. W rezultacie obniżające się ceny wyzwalają wzrost produkcji, a nie jej spadek, jak w poprzednich okresach, gdy spadek cen wywoływał spadek podaży pojawiający się po pewnym okresie czasu. Obecnie mamy do czynienia z małymi wahaniami ubojów w krótkim okresie i długookresową tendencją wzrostową podaży. Ten stały wzrost podaży można uznać za ważny czynnik minimalizowania skali krótkookresowych wahań produkcji trzody, jaki ma miejsce w ostatnich latach.

Powstaje jednak pytanie, dlaczego amplituda wahań cen jest tak duża w sytuacji tak małej amplitudy wahań podaży? Większe zmiany cen trzody niż ubojów nie powinny budzić zdziwienia, gdyż popyt na żywność, w tym na wieprzowinę jest nieelastyczny w krótkim okresie i nawet mała zmiana podaży może powodować dużą zmianę ceny (Małkowski, 1971; Małkowski, 1986; Małkowski, 1998). Ma to związek z giętkością cen. Jeśli popyt jest nieelastyczny względem cen, to odpowiada on cenom giętkim, co oznacza, że jeśli podaż zmieni się o jednostkę, to cena może się zmienić o kilka jednostek.

W warunkach globalizacji istotnym czynnikiem wpływającym na wahania cen są jednak także wahania kursów walutowych. W przypadku Stanów Zjednoczonych najważniejsze kursy walutowe to te, które dotyczą rynków kluczowych dla amerykańskiego handlu wieprzowiną, a więc po stronie eksportu Meksyk i Japonia, a po stronie importu Kanada.

Tabela 2. Współczynniki korelacji pomiędzy cenami trzody, a kursem dolara do innych walut oraz pomiędzy cenami trzody a eksportem i importem

Table 2. Correlation coefficient between pig prices and dollar exchange rates and between pig prices and export, import

\begin{tabular}{lc|lc}
\hline \multicolumn{2}{c|}{ Współczynniki korelacji pomiędzy cenami trzody } & \multicolumn{2}{c}{ Współczynniki korelacji pomiędzy cenami trzody a: } \\
\hline Dolara kanadyjskiego & $-0,71$ & Eksportem wieprzowiny & 0,62 \\
Jena japońskiego & 0,57 & Eksportem żywych zwierząt & 0,14 \\
Peso meksykańskiego & 0,54 & Importem wieprzowiny & $-0,32$ \\
Dolar Hongkongu & 0,62 & Importem żywych zwierząt & $-0,49$ \\
\hline
\end{tabular}

Źródło: obliczenia własne na podstawie danych NASS/USDA oraz Federal Reserve Bank of St. Luis.

W 2015 r. eksport do Meksyku i Japonii stanowił odpowiednio 34\% i 19\%, co łącznie wynosiło 53\% ogólnego eksportu żywca i mięsa wieprzowego. Import z Kanady dotyczył tak żywych zwierząt, jak i wieprzowiny. W 2015 r. 87\% import wieprzowiny z Kanady stanowił $76 \%$ amerykańskiego importu wieprzowiny, a import żywych zwierząt to prawie $100 \%$ całego importu tej kategorii.

Współczynniki korelacji między kursem dolara amerykańskiego do dolara kanadyjskiego, jena japońskiego, peso meksykańskiego i dolara Hongkongu, a cenami trzody w USA wskazują, że wpływ wymienionych kursów walut na ceny trzody na rynku amerykańskim jest statystycznie istotny. Największy wpływ na te ceny ma kurs dolara 
USA do dolara kanadyjskiego, co w świetle wzajemnych powiązań tych rynków jest zupełnie zrozumiałe. Wysoki współczynnik charakteryzuje też korelacje między kursem dolara amerykańskiego do dolara Hongkongu. Wynika to ze wzrostu eksportu w tym kierunku. Tylko w latach 2006-2015 eksport ten zwiększył się z 88 tys. ton do 339 tys. ton, a więc prawie czterokrotnie, a jego wartość ze $126 \mathrm{mln}$ USD do $700 \mathrm{mln}$ USD, a więc prawie sześciokrotnie.

Zależność pomiędzy cenami trzody, a kursem dolara do walut wziętych pod uwage można wytłumaczyć następująco. Wzrost kursu powoduje wzrost eksportu, a więc inaczej mówiąc wzrost popytu zewnętrznego na wieprzowinę. Jednocześnie ograniczony zostaje import, czyli podaż na rynku wewnętrznym. W rezultacie wzrostu popytu i spadku podaży ceny trzody rosną. Z kolei spadek kursu poprawia opłacalność importu i pogarsza opłacalność eksportu. Inaczej mówiąc wpływa na obniżenie popytu i wzrost podaży, co prowadzi do spadku cen trzody na rynku wewnętrznym. W tej sytuacji wszelkie zmiany koniunktury na świecie, a zwłaszcza na rynkach krajów najbardziej powiązanych z rynkiem trzody Stanów Zjednoczonych takich, jak Kanada, Japonia czy Meksyk odbijają się na rynku wewnętrznym. W ostatnich latach prawie jedna czwarta produkowanej w Stanach Zjednoczonych wieprzowiny podlega eksportowi, w związu z tym wrażliwość cen trzody tak na eksport, jak i na import jest bardzo duża. Po stronie eksportu większe znaczenie ma eksport mięsa niż żywych zwierząt, a po stronie importu odwrotnie.

\section{Podsumowanie}

Zmiana warunków rynkowych wywarła duży wpływ na amplitudę wahań produkcji trzody w Stanach Zjednoczonych. Z naszej analizy wynika, że amplituda wahań produkcji trzody w Stanach Zjednoczonych w ostatnich latach stała się mniejsza niż w poprzednich dziesięcioleciach. Przyczyn tego upatrujemy w oddziaływaniu na ten rynek czynników, które zadecydowały o zmianie relacji współczynników elastyczności podaży i popytu. Elastyczność podaży stała się mniejsza niż elastyczność popytu. Jest to jeden z przypadków teorematu pajęczyny (przypadek wahań zbieżnych). Czynnikiem tym jest według nas jest wzrost skali produkcji i jej usztywnienie wysokim udziałem kosztów stałych, a także zmiana kanałów rynkowych i sposobów wyceny tuczników.

Niezależnie jednak od małych wahan produkcji, ceny trzody cechuje nadal duża amplituda wahań i częstość ich występowania. Dzieje się tak, z dwu powodów. Z jednej strony zgodnie $\mathrm{z}$ teorią ekonomii usztywnionemu popytowi towarzyszy giętkość cen. $\mathrm{Z}$ drugiej strony wahania cen żywca są tak samo silne jak dawniej, gdyż wpływ na nie ma nie tylko popyt wewnętrzny, ale także zewnętrzny. Poprzez kursy dolara do walut krajów, z którymi Stany Zjednoczone prowadzą handel zagraniczny wieprzowiną przejawia się wpływ handlu zagranicznego i rynku globalnego na opłacalność i na rynek krajowy.

Dla rozwoju wiedzy $\mathrm{z}$ tego zakresu niewatpliwie cennym byłoby obliczenie współczynników cenowej elastyczności popytu i podaży wieprzowiny w różnych okresach i pokazanie faktycznych zmian w ich wzajemnych relacjach. Wówczas można by określić czy rzeczywiście elastyczność podaży stała się mniejsza niż elastyczność popytu. Jest to jeden z przypadków teorematu pajęczyny (przypadek wahan zbieżnych). Z obecnego punktu widzenia wydaje się, że relacje elastyczności popytu i podaży są okresowo stałe. Wystarczy jednak czynnik lub grupa czynników by doszło do usztywnienia jednej ze stron. 
Takim czynnikiem jest prawdopodobnie wzrost skali produkcji usztywniający podaż wysokim udziałem kosztów stałych.

\section{Literatura}

Barkema, A, Drabenstott, M, Novack, N. (2001). The New U.S. Meat Industry, Economic Review, 2nd Quarter, 33-56.

Hanau, A. (1927). Die Prognose der Schweinepreise, Vierteljahrshefte fur Koniunkturforschung, Sonderhefte 7 , Berlin Verlag, Dostępne online: http://www.diw.de/documents/dokumentenarchiv/17/43353/viertel 1928.pdf

Lawrence, J.D., Hayenga, M. (2002). The U.S. pork and beef sectors: divergent organizational patterns, paradoxes and conflicts. Iowa State University.

Małkowski, J. (1971). Efektywność regulowania produkcji i podaży żywca wieprzowego, Spółdzielczy Instytut Badawczy. Seria Rynku Wiejskiego, Warszawa

Małkowski, J. (1985). Wahania produkcji trzody chlewnej, Wieś Współczesna, Warszawa nr 5, 21-41.

Małkowski, J.(1986). Produkcja i spożycie mięsa w Polsce i USA, Studia i Monografie zeszyt 24, IERiGŻ, Warszawa.

Małkowski, J. (1998). hasło Cykl świński, W: Encyklopedia Agrobiznesu, A. Woś (red.), Fundacja Innowacja, Wyższa Szkoła Społeczno-Ekonomiczna, Warszawa, 106-108.

Martinez, St. W. (2002A). The U.S. Pork Industry as it Changes Consumers. Stand to Benefit, Agricultural Economic Report, USDA, 1-45.

Martinez, St.W. (2002B). Vertical Coordination of Marketing Systems, Lesson From The Poultry, Egg and Pork Idustries, Agricultural Economic Report, USDA, 1-45.

Plain, R. (2016). U.S. Market Hog Sales, 2002-2015. University of Missouri. Dept. of Agricultural and Applied Economics.

Schmidt, S., Mandecki, S. (1933). Produkcja trzody w świetle badań koniunkturalnych, Nakładem Towarzystwa Ekonomicznego w Krakowie.

Schmidt, St., Steczkowski, J. (1960). Produkcja żywca i mięsa wieprzowego w świetle statystyki, Zagadnienia Ekonomiki Rolnej, z.4.

Schmidt, St., Steczkowski, J. (1975). Zmienność w produkcji trzody chlewnej i możliwości jej regulowania. Cz.1. Folia Oeconomica Cracoviensia nr 17.

Zawadzka, D. (2005). Koncentracja pogłowia trzody chlewnej w wybranych krajach Unii Europejskiej i w Stanach Zjednoczonych, Trzoda Chlewna $\mathrm{nr}$ 1, 6 .

Zawadzka, D. (2006A). Historia badań cyklu świńskiego, Zagadnienia Ekonomiki Rolnej

Zawadzka, D. (2006B). Formy koordynacji pionowej w sektorze trzody chlewnej w Stanach Zjednoczonych i w Danii, Zagadnienia Ekonomiki Rolnej, nr 1, 60-70.

Zawadzka, D. (2006C). Koordynacja pionowa w sektorze trzody chlewnej w Stanach Zjednoczonych i w Danii, Trzoda Chlewna, 2, 13-16.

Zawadzka, D. (2014). Cykl świński, a funkcjonowanie rynku żywca wieprzowego, praca doktorska, IERiGŻ-PIB, Warszawa. 